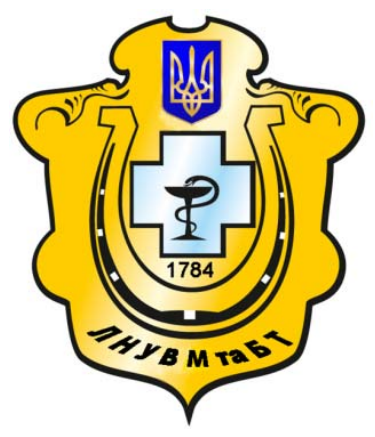

Науковий вісник Львівського національного університету ветеринарної медицини та біотехнологій імені С.3. Гжицького

Scientific Messenger of Lviv National University of Veterinary Medicine and Biotechnologies named after S.Z. Gzhytskyj

doi:10.15421/nvlvet7326

ISSN 2518-7554 print

ISSN 2518-1327 online

$\underline{\text { http://nvlvet.com.ua/ }}$

\title{
Відтворювальна здатність і структурно-функціональний стан матки щурів, які споживали корми $320 \%$ вмістом ГМ-сої
}

\author{
Г.І. Коцюмбас, І.М. Самсонюк, М.І. Шкіль \\ galyna.kotsyumbas@gmail
}

Львівський національний університет ветеринарної медицини та біотехнології імені С.3. Гжицького, вул. Пекарська, 50, м. Львів, 79010, Украӥна

\begin{abstract}
У статті представлено динаміку змін показників фертильності самок I, II $i$ III поколінь щурів та морфофункиіонального стану матки шурів І покоління, яким згодовували корми з 20\% вмістом традиційної та генетично модифікованої сої. Отримано три покоління щурів, які спожсивали корм з 20\% вмістом ГМ $і$ традиційної сої. Відтворювальну здатність оцінювали за фертильністю тварин. На 135 добу життя по 5 шурематок з кожної групи (60 добу після родів) виводили з експерименту шляхом ефірного наркозу, декапітували, відбирали матку для гістологічного і гістохімічного дослідження, яку фіксували у 10\% розчині нейтрального формаліну, рідині Карнуа з наступною заливкою у парафін. Виготовляли гістозрізи, фарбували гематоксилін-еозином, за Мак-Манусом у поєднанні з альціановим синім.

Встановлено, щзо довготривале згодовування кормів з 20\% вмістом ГМ сої негативно відобразилось на I поколінні тварин, ще виразилось зниженням відтворювальної здатності самок щурів та тендениійним зниженням кількості голів новонароджених щуренят у гнізді і вірогідним зменшенням загальної кількості щуренят. У двох наступних поколіннях самок щурів II і III груп вірогідних відмінностей у досліджуваних показниках не виявлено, щуо, ймовірно обумовлено включенням адаптаційно - компенсаторних механізмів на зміну рачіону годівлі.

За гістологічного дослідження матки шурів І покоління, які вживали корми з 20\% вмістом сої встановлено зменшення секреції глікозаміногліканів, щуо призвело до послаблення бар'єрного захисту, ушкодження епітеліальних клітин, розвитку атрофічних проиесів у міометрії та ендометрію, кистоподібного розиирення одних маткових залоз і вакуольної дистрофіі епітелію інших, лімфоїдно-гістіоцитарної інфільтрації власної пластинки ендометрію, щуо вказувало на зниження морфофункціонального стану матки.
\end{abstract}

Ключові слова: щурі, матка, ГМ-соя, гістологія,гістохімія, фертильність.

\section{Воспроизводительные свойства и структурно-функциональное состояние матки крыс, корорые употребляли корма из 20\% содержанием ГМ-сои}

\author{
Г.И. Коцюмбас, И.М. Самсонюк, М.И. Шкиль \\ galyna.kotsyumbas@gmail
}

Львовский национальный университет ветеринарной медицины и биотехнологии имени С.3. Гәицкого, ул. Пекарская, 50, г. Львов, 79010, Украина

В статье представлена динамика изменений показателей фертильности самок I, II и III поколений крыс и морфофункционального состояния матки крыс I поколения, которым скармливали корма с 20\% содержанием традиционной и генетически модифицированной сои. Получено три поколения крыс, которые употребляли корма с 20\% содержанием ГМ и традииионной сои. Воспроизводительную способность оиенивали по фертильности животных. На 135 сутки жизни по 5 крыс из каждой группы (60 сутки после родов) выводили из эксперимента путем эфирного наркоза, декапитировали, отбирали матку для гистологического и гистохимического исследования, которую фиксировали в 10\% растворе нейтрального фор-

Citation:

Kotsjumbas,G., Samsonjuk, I., Shkilj, M. (2017). Reproductive capacity and structural and functional status rats uterus that consumed feed containing 20\% GM-soy. Scientific Messenger LNUVMBT named after S.Z. Gzhytskyj, 19(73), 126-130. 
малина, жидкости Карнуа с последующей заливкой в парафин. Изготовляли гистосрезы, окрашивали гематоксилинэозином, по Мак-Манус в сочетании с альцииановый синим.

Установлено, что длительное скармливание кормов с 20\% содержанием ГМ сои отрицательно отразилось на І поколении животных, выразилось снижением воспроизводительной способности и тенденциозным снижением количества голов новорожденных крысят в гнезде и уменьшением общего количества крысят. В двух последуюших поколениях самок крыс II и III групп достоверных различий в исследуемых показателях не обнаружено, что, вероятно обусловлено включением адаптационно - компенсаторных механизмов на смену рачиона кормления.

При гистологическом исследовании матки крыс I поколения, которые употребляли корма с 20\% содержанием сои установлено уменьшение секреции гликозаминогликанов, что привело к ослаблению барьерной защить, повреждению эпителиальных клеток, развитию атрофических процессов в миометрии и эндометрии, кистообразному расиирению одних маточных желез и вакуольной дистрофии других, лимфоидно-гистиоцитарной инфильтрации собственной пластинки эндометрия,что указывало на снижение морфофункциональных состояния матки.

Ключевые слова: крысы, матка, ГМ-соя, гистология, гистохимия, фертильность.

\title{
Reproductive capacity and structural and functional status rats uterus that consumed feed containing $20 \%$ GM-soy
}

\author{
G. Kotsjumbas, I. Samsonjuk, M. Shkilj \\ galyna.kotsyumbas@gmail \\ Lviv National University of Veterinary Medicine and Biotechnologies named after S.Z. Gzhytskyj, \\ Pekarska st., 50, Lviv, 79010, Ukraine
}

The article presents the dynamics of changes in female fertility of I, II and III generations of rats and morph functional state of rats uterus of I generation, which were fed with feed containing $20 \%$ traditional and genetically modified soy. Received three generations of rats that consumed feed containing $20 \%$ of GM and traditional soybeans. It was received generation of rats that consumed feed containing $20 \%$ of GM and traditional soybeans. The reproductive ability was evaluated by the fertility of animals. On 135 day of life 5 rat females from each group (60 days after birth) were taken out of the experiment through ether anesthesia, were decapitated, the uterus were taken for histological and histochemical research, which were fixed in 10\% solution of neutral formalin, Karnua liquid, followed by pouring into paraffin. It was produced histoslices, stained with hematoxylin-eosin, by McManus combined with altsianic blue.

It was established that long-term feeding of feed containing 20\% GM soya negatively affected the 1 generation of animals, as expressed lowering of reproductive capacity of female rats and tendentious decrease in the number of heads of newborns in the young rat nests. In the next two generations of female rats of II and III groups probable differences in the investigated indices were not found which is probably due to the inclusion of adaptive compensatory mechanisms to change feeding ration.

For histological examination of the rats uterus of the I generation, who consumed feed containing $20 \%$ soybean was set to reduce the secretion of glycans replacement, which has reduced barrier protection, damage of epithelial cells, development of atrophic processes in the myometrium and endometrium, cyst like extension of one uterine glands and vacuolic epithelial dystrophy of others, lymphoid-histiocytic infiltration of the lamina propria of the endometrium, indicating that the decline in morphological functional state of the uterus.

Key words: rats, uterus, GM-soya, histology, histochemistry, fertility.

\section{Вступ}

На даний час у багатьох країнах світу відзначається масштабне розповсюдження генномодифікованих організмів (ГМО). Соя є найпопулярнішою сільськогосподарською культурою, продукти якої широко використовуються як в харчовій промисловості, так і як кормова добавка при відгодівлі тварин. 90\% усієї сої, що надходить на світовий ринок становить генетично модифікована соя «Roundup Ready» (RR), яка володіє геном стійкості до гербіциду.

На сьогодні, генномодифіковані культури входять до складу хліба, печива, морозива, чіпсів, шоколаду, соевого молока і т.д., використовуються у продуктах харчування для дітей, підлітків і молодих людей. За даними експериментальних досліджень на тваринах показано, що постійне використання ГМ-сої може стати причиною виникнення патологічних процесів в організмі живих істот, зокрема в репродуктивних органах самців і самок (Ermakova and Barskov, 2008).

Актуальність теми. Аналізуючи результати дослідження науковців щодо застосування раундапостійкої сої при відгодівлі тварин, більшість із них відзначають негативний вплив на потомство i структурно-функціональний стан репродуктивних органів, зміну гормонального стану організму, розвиток неплідності тощо (Dolaichuk et al., 2012). Одні автори вказують, що 3 додаванням до корму трансгенної сої у продовж трьох поколінь встановлено відставання в рості i розвитку, порушення співвідношення статей у виводках із збільшенням частки самок, зменшення кількості потомства, аж до його повної відсутності у другому поколінні (Mykhailov and Shcherbyna, 2013). Інші дослідники відзначають зниження статевої активності у другому поколінні у кнурців, збільшення тривалості на 7 днів супоросності у свинок та зростання мертвонароджуваності (Kulyk et al., 2015). На негативний вплив ГМ- компонентів у кормах на репродуктивну функцію самців і самок та безпліддя в наступних поколіннях вказують проведені дослідження в університеті Касна (Франція, 2006) на популяції хом'яків. Довготривале згодовування раундапостійкої ГМ сої білим щурам спричинило у 
них розвиток морфофункціональних змін сім'яників у четвертому поколінні (Rautskiiene and Havryliuk, 2016).

Одже, масштабне запровадження методів трансформації геному рослин, призвело до необхідності ретельної перевірки можливих віддалених негативних наслідків їх використання. Адже, цей процес незворотній і вимагає досконалого всебічного, науково - обгрунтованого дослідження. У зв'язку 3 цим перед дослідниками стоїть завдання глибокого вивчення тривалого впливу трансгенних культур та їх метаболітів на органи і системи живого організму.

Мета $і$ завдання дослідження. Метою роботи було з'ясувати динаміку змін показників фертильності самок, деяких показників крові I, II і III поколінь щурів та морфофункціонального стану матки щурів I покоління, яким згодовували корми з 20\% вмістом традиційної та генетично модифікованої сої.

\section{Матеріал і методи досліджень}

Дослідження проводилось на щурах лінії Вістар вагою 160-180 г, віком 3,5-4 місяці. Було сформовано 3 групи тварин, по 14 щурів у кожній (8 самок і 6 самців). I група - контрольна, які одержували стандартний корм віварію. II група - щурам згодовували корм 3 додаванням 20\% традиційної сої сорту «Аннушка». III група - тварини отримували корм 3 додаванням 20\% генномодифікованої сої (сорт «Roundap Ready» лінії 40-3-2, який містить трансгени ср4epsps та регуляторні елементи - промотор E35S і термінатор NOS).

Зразки сої обох сортів перевірялись на наявність генетичної модифікації, що підтверджено протоколом №2709/1-Л/03. У зразку №1 цільові послідовності промотора $35 \mathrm{~S}$ вірусу мозаїки цвітної капусти (CaMV) та термінатора NOS (T-NOS) Т1плазміди Agrobacterium tumifaciens. Соєві боби перед додаванням у корми подрібнювались і термічно оброблялись при $\mathrm{t} 140^{\circ}$ протягом 2 год., для знешкодження антипоживних речовин та зниження уреазної активності. Комбікорми для дослідних тварин були збалансовані і пройшли випробування у лабораторії контролю кормових добавок і преміксів (Протокол № 2709/3 від 28.10.11p.). За тваринами протягом досліду вели спостереження. На 135 добу життя тварин зважували.

Отримано три покоління щурів, які споживали корм з 20\% вмістом ГМ і традиційної сої. Відтворювальну здатність оцінювали за фертильністю тварин здатність самок до запліднення, що виразилось у відсотковому відношенні кількості запліднених самок до загальної кількості спарованих самок. Для оцінки постнатального розвитку приплоду визначали кількість народжених щуренят, мертвонароджених та здатністю до виживання у перші два місяці.

У тварин відбирали кров, по 5 щурематок 3 кожної групи (60 добу після родів) виводили з експерименту шляхом ефірного наркозу, декапітували, проводили автопсію. 3 показників крові визначали: кількість еритроцитів, лейкоцитів - в камері Горяєва; лейкоцитарну формулу методом візуальної мікроскопічної оцінки сухих, фіксованих, зафарбованих за МайГрюнвальдом мазків та гемоглобін - гемоглобінціанідним методом.

Для морфологічних досліджень відбирали взірці матки, які фіксували у $10 \%$ розчині нейтрального формаліну, рідині Карнуа, зневоднювали у висхідному ряді спиртів та заливали в парафін за загальноприйнятою методикою. 3 парафінових блоків на санному мікротомі МC-2, виготовляли серійні парафінові зрізи, товщиною 3-6 мкм, які фарбували гематоксиліном та еозином, за Мак-Манусом у поєднанні з альціановим синім [Меркулов]. Світлову мікроскопію, мікрофотографування гістопрепаратів здійснювали за допомогою мікроскопа OLYMPUS CX 41 та фотокамери OLYMPUS C-5050.

\section{Результати та їх обговорення}

Тривалі спостереження за дослідними тваринами показали, що згодовування щурам ГМ сої призвело у першому поколінні до вірогідного зниження фертильності самок. Кількість незапліднених самок у III дослідній групі першого покоління становило 50\% від загальної кількості самок, тоді як у II дослідній групі щурів, які споживали традиційну сою, 38 самок у групі запліднення відбулося в усіх 8 щурематок. У контрольній групі процент незапліднених самок становив всього $12,5 \%$.

У щурематок другого покоління вірогідного зниження фертильності не виявлено. Процент незапліднених самок II і III груп був невисоким і становив $12,5 \%$, тоді як у контрольній групі показник фертильності становив $100 \%$.

У третьому поколінні, в III групі самок, які споживали з кормом ГМ сою, відзначали 100\% запліднення, однак відзначали вірогідне зниження маси тіла у щурів на 26\% відносно контролю. У щурів II групи, які 3 кормом отримували традиційну сою, процент незапліднених самок складав 12,5\% від загальної кількості самок. У контрольній групі цей показник становив $100 \%$.

При вивченні лейкограми крові щурематок I покоління III групи (F0) виявлено вірогідне зниження стосовно контролю кількості лейкоцитів - на 24,4\%. Загальна кількість лейкоцитів крові у контрольній групі становило 4,5 тис./мкл., тоді як у III групі 3,4 тис./мкл. Разом $з$ тим слід відзначити, що у щурів II i III груп кількість еритроцитів знаходилась на нижній межі встановленої фізіологічної норми 5,7; 5,6 × $10^{12} /$ л. У другому поколінні вірогідних змін між групами не виявили, кількість клітинного складу крові знаходилась у межах фізіологічної норми в усіх трьох групах, а вміст гемоглобіну у III дослідній групі зростав на 33\% стосовно контролю. Трете покоління характеризувалось стабільним станом щодо гематологічних показників, всі вони знаходились в межах фізіологічної норми і вірогідних відмінностей між групами не виявлено.

За гістологічного дослідження тіла матки щурів III групи I покоління, які не родили у порівнянні із самками щурів контрольної групи відзначали певні структурні відмінності: значне зменшення товщини ендо- 
метрію та міометрію, з одночасним розширення кровоносних судин, що вказувало на розвиток атрофічних процесів у структурах матки.

У щурів контрольної групи одношаровий покривний епітелій ендометрію чітко структурований, при фарбуванні за Мак-Манусом у поєднанні з альціановим синім помірно вкритий слизом з високим вмістом глікозаміногліканів. Маткові залози переважно вистелені епітелієм 3 однорідно забарвленою цитоплазмою, в яких чітко проглядались контури клітин і базофільні ядра (рис. 1). При мікроскопічному дослідження ендометрію щурематок III групи I покоління, які не родили, виявили в одних осередках ендометрію покривний епітелій набубнявілий, потовщений, вкритий PAS-позитивним слизом, який не містив

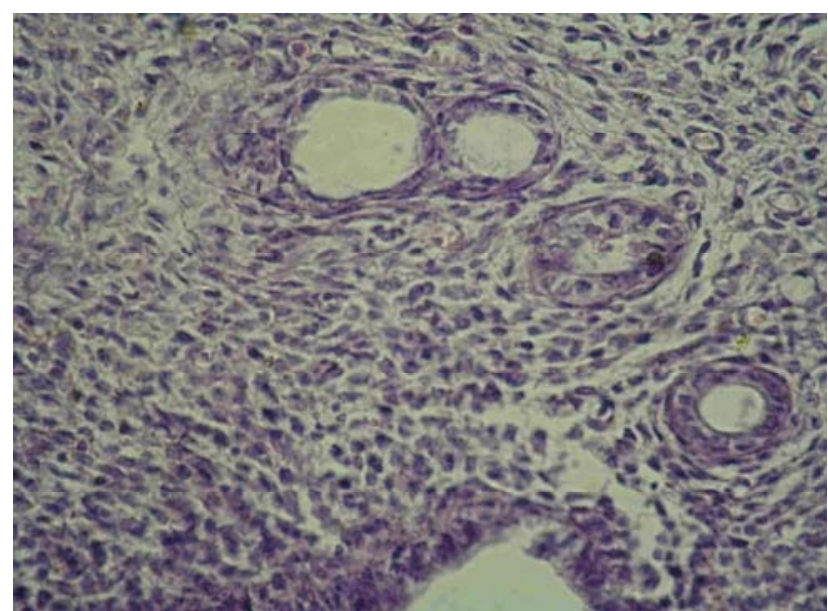

Рис. 1. Ендометрій щурів контрольної групи.

Маткові залози вистелені епітелієм $з$ однорідно забарвленою цитоплазма.

Гематоксилін та еозин. Ок.10, об. 40

У інших тварин виявляли зростання кистоподібно розширених маткових залоз 3 атрофією епітелію (рис. 3,4$)$. При цьому їх просвіт розширений, епітеліальні клітини місцями відторгнуті від базальної мем-

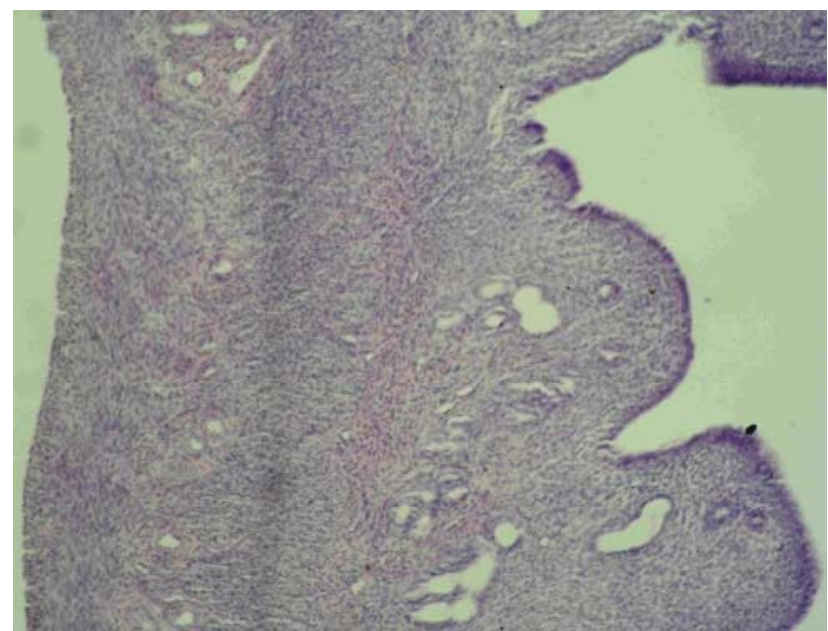

Рис. 3. Ендометрій щурів III групи. Кистоподібно розширені маткові залози.

Гематоксилін та еозин. Ок.10, об. 20 глікозаміногліканів. Зменшення вмісту глікозаміногліканів на апікальній поверхні епітеліальних клітин слизової оболонки вказує на зниження захиснопристосувальної функції матки. У власній пластинці відзначали помірну клітинну інфільтрацію із гістіоцитів, тучних клітин, лімфоїдних елементів. Просвіт маткових залоз в таких ділянках звужений або не проглядався. В інших ділянках ендометрію епітелій маткових залоз набубнявілий, цитоплазма просвітлена, розріджена, у деяких вакуолізована, контури клітин порушені. Ядра таких клітин лізовані, або пікнотичні. Виявлені зміни вказували на розвиток вакуольної дистрофії та некробіотичні зміни епітелію маткових залоз (рис. 2).

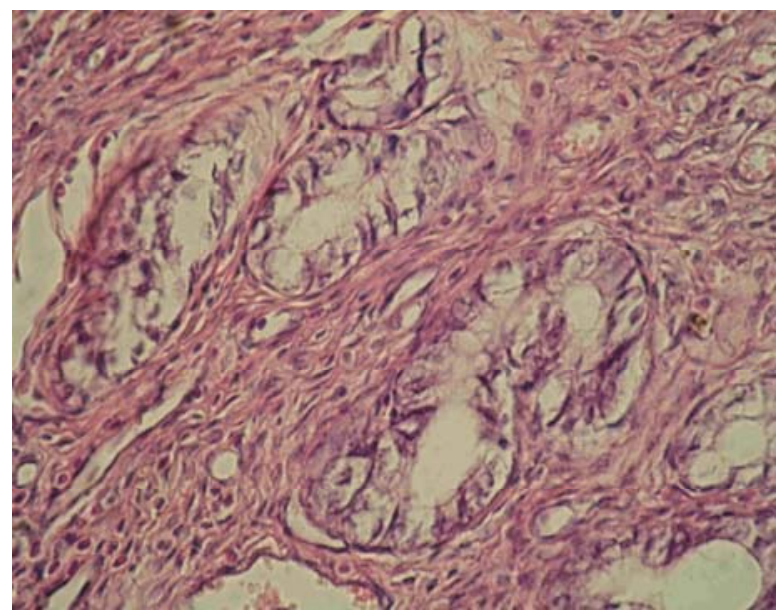

Рис. 2. Ендометрій щурів III групи. Вакуольна дистрофія епітелій маткових залоз.

Гематоксилін та еозин. Ок.10, об. 40

брани. Ендометрій у цих ділянках нерівний, набубнявілий, місцями просвітлений. Поряд 3 ними виявляли маткові залози вистелені структурованим кубічним епітелієм.

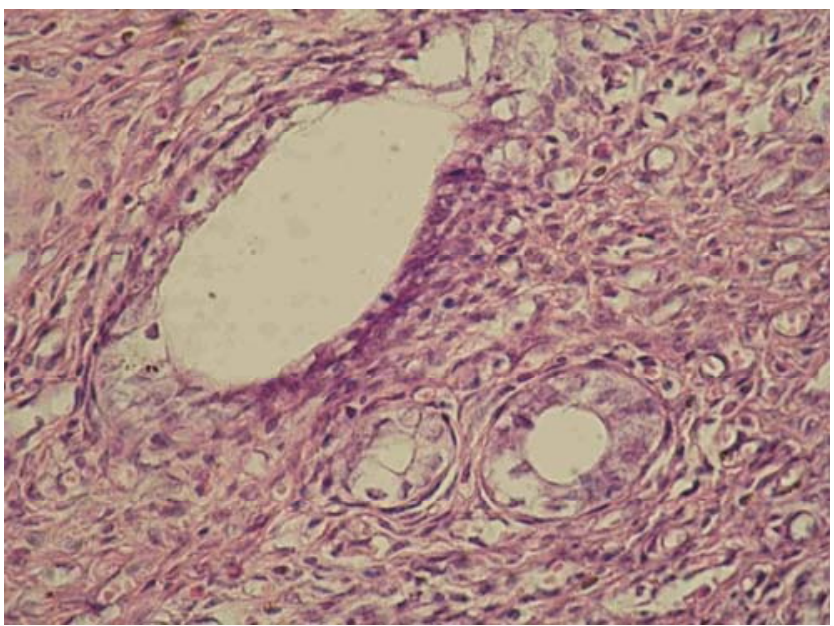

Рис. 4. Ендометрій щурів III групи. Атрофія епітелію кистоподібно розширених маткових залоз. Гематоксилін та еозин. Ок.10, об. 40 


\section{Висновки}

1. Довготривале згодовування кормів з $20 \%$ вмістом ГМ сої негативно відобразилось на I поколінні тварин, що виразилось зниженням відтворювальної здатності щурематок та тенденційним зниженням кількості голів новонароджених щуренят у гнізді і вірогідним зменшенням загальної кількості щуренят. У двох наступних поколіннях щурематок II і III груп вірогідних відмінностей у досліджуваних показниках не виявлено, що, ймовірно обумовлено включенням адаптаційно - компенсаторних механізмів на зміну раціону годівлі.

2. За гістологічного дослідження матки щурів I покоління, які вживали корми з 20\% вмістом сої встановлено зменшення секреції глікозаміногліканів, що призвело до послаблення бар'єрного захисту, ушкодження епітеліальних клітин, розвитку атрофічних процесів у міометрії та ендометрії, кистоподібного розширення одних маткових залоз і вакуольної дистрофії епітелію інших, лімфоїдно-гістіоцитарної інфільтрації власної пластинки ендометрію, що вказувало на зниження морфофункціонального (репродуктивного) стану матки.

Перспективи подальших досліджень. У подальшому планується дослідити структурнофункціональний стан матки і сім'яників щурів II і III поколінь, яким тривалий час згодовували корми з $20 \%$ вмістом ГМ-сої.

\section{Бібліографічні посилання}

Dolaichuk, O.P., Matiukha, I.O., Fedoruk, R.S. (2012). Pokaznyky reproduktyvnoi zdatnosti ta koefitsiienty masy vnutrishnikh orhaniv samok shchuriv u protsesi dii komponentiv naturalnoi ta transhennoi soi. Naukovyi visnyk Volynskoho nats. untu imeni Lesi Ukrainky. Rozdil III.Fiziolohiia liudyny i tvaryny, 5560 (in Ukrainian).

Ermakova, I.V., Barskov, I.V. (2008). Izuchenie fiziologicheskih i morfologicheskih parametrov u krys i ih potomstva pri ispol'zovanii diety soderzhashhej soju s transgenom ERSPS SR 4. Sovr. probl.nauki i obrazovanija. Biol. nauki. 6, 19-20 (in Russian).

Kulyk, M.F., Kulyk, Ya.M., Obertiukh, Yu.V., Khimich, V.V. (2015). Vplyv dovhotryvaloho zghodovuvannia transhennoi soi na vidtvoriuvalnu zdatnist svynei. Henetyka i rozvedennia. 49, 213-220 (in Ukrainian).

Merkulov, G.A. (1969). Kurs patologogistologicheskoj tehniki. Moskva: Medicina (in Russian).

Mykhailov, V.H., Shcherbyna, O.Z. (2013). Navishcho nam transhenna soia? Posibnyk ukrainskoho khliboroba.: naukovo-praktychnyi zbirnyk. K.: TOV «AKADEMPRES». 2, 165-168 (in Ukrainian).

Rautskiiene, V.P., Havryliuk, A.O. (2016). Patomorfolohichni zminy simianykiv eksperymentalnykh tvaryn chetvertoho pokolinnia pry postiinomu vzhyvanni raundapostiikoi henetychno modyfikovanoi soi. " Materialy KhIII Mizhnarodnoi naukovoi konf.stud. i molodykh vchenykh «Pershyi krok v nauku - 2016». M. Vinnytsia, 54 (in Ukrainian).

Стаття надійшла до редакиї 3.03.2017 